\title{
DETERMINAN PREFERENSI MASYARAKAT KOTA MEDAN DALAM MENGGUNAKAN PEMBAYARAN NONTUNAI
}

\author{
M. Ridwan ${ }^{1}$, Nurlalia ${ }^{2}$, Rangga Salam 3 \\ 1,2,3 Universitas Islam Negeri Sumatera Utara \\ 1,2,3 Jalan William Iskandar Ps. V, Medan Estate Kec. Percut Sei Tuan, Kab. Deli Serdang \\ 20371, Sumatera Utara Indonesia \\ 1 mridwanku@uinsu.ac.id \\ 2 laila_harahap@yahoo.co.id \\ 3salamrangga14@gmail.com
}

\begin{abstract}
This study aims to determine whether efficiency, liability, security, convenience and discounts on people's preferences on cashless payment in the city of Medan. This type of research consists of quantitative analysis. In this study is a description or explanation of the results of data collection which then analyzed obtained a clear explanation of the research. The respondents are employees, research workers, students and people invited related in this research. Based on analysis result showed that efficiency, obligation, security, convenience and discounts have influenced to community preferences partially. Simultaneously, there are positive and significant influence of efficiency, obligation, security, convenience and discounts to community preferences.
\end{abstract}

Keywords: Cashless, Payment, Preferences

\begin{abstract}
Abstrak
Penelitian ini bertujuan untuk mengetahui efisiensi, kewajiban, keamanan, kemudahan dan diskon berpengaruh pada preferensi masyarakat Kota Medan dalam menggunakan pembayaran nontunai. Jenis penelitian ini berupa analisis kuantitatif yang merupakan uraian atau penjelasan dari hasil pengumpulan data yang kemudian dianalisis sehingga diperoleh gambaran yang jelas mengenai objek penelitian. Responden penelitian meliputi karyawan, pelaku usaha, mahasiswa serta pihak yang dinilai relevan dalam menjawab permasalahan pada penelitian ini. Berdasarkan analisis pengolahan data diperoleh hasil bahwa secara parsial terdapat pengaruh efisiensi, kewajiban, keamanan, kemudahan dan diskon terhadap preferensi masyarakat dalam menggunakan pembayaran nontunai. Sementara itu, secara simultan terdapat pengaruh positif dan signikan efisiensi, kewajiban, keamanan, kemudahan dan diskon terhadap preferensi masyarakat dalam menggunakan pembayaran nontunai.
\end{abstract}

Kata Kunci: Nontunai, Pembayaran, Preferensi 


\section{PENDAHULUAN}

Teknologi digital adalah sebuah terobosan serta inovasi baru dalam seluruh kegiatan ekonomi saat ini. Hal tersebut memengaruhi dan berdampak langsung pada sektor keuangan. Salah satu sektor yang paling berkembang adalah finansial technology atau lebih dikenal dengan istilah fintech. Munculnya fintech ini diharapkan dapat meningkatkan kesejahteraan masyarakat melalui pembayaran yang berbasis teknologi. Masyarakat menentukan pilihannya dalam melakukan transaksi pembayaran atau jual beli. Saat ini sistem ekonomi sedang dalam proses perkembangan ekonomi yang berbasis teknologi, dimana setiap orang hari ini tidak dapat terhindar dari teknologi. Kehadiran electronic money (e-money) didasari oleh Peraturan Bank Indonesia Nomor 11/12/PBI/2009 sebagai salah satu pendukung agenda Bank Indonesia untuk menciptakan less cash society di Republik Indonesia. E-money pada dasarnya bertujuan untuk memudahkan manusia dalam melakukan berbagai macam transaksi ekonomi di kehidupannya (TOC - Bagaimana Implementasi Pembayaran Nontunai Berbasis Aplikasi Yang Ideal?, n.d.). E-money adalah solusi transaksi mikro modern (Nur, 2013). Emoney terbukti mampu memberi keamanan, kenyamanan dan kemudahan di berbagai Negara (Hidayati et al., 2006). Perkembangan uang elektronik sangat pesat, pertama kali terbit tahun 2009 hanya sebanyak 165.193 instrumen, dan terus meningkat sampai tahun 2013 sebanyak 36.225.373, tetapi awal tahun 2014 mengalami penurunan 4\% dari jumlah akhr tahun 2013. Sedangkan pertengahan tahun 2015 pada bulan September sampaiakhir tahun 2017 selalu meningkat hal ini dapat di sebabkan karena adanya faktor perdagangan bebas Asean Economic Comunity 2015 yang dilakukan oleh Indonesia dengan negara-negara ASEAN tahun 2015 yang merupakan negara integrasi antara negara-negara ASEAN yang melakukan perdagangan bebas dengan tujuan memenuhi kebutuhan negara nya dan peningkatan kesejahteraan dengan keunggulan mutlak dari negaranya (Rohmah, n.d.)

Berbagai sistem pembayaran sering dilakukan di dalam kehidupan sehari - hari dengan alat bayar yang sah, baik itu dengan cara tunai maupun nontunai. Sistem pembayaran didefinisikan sebagai suatu sistem yang di dalamnya mencakup seperangkat aturan, lembaga dan mekanisme yang digunakan untuk melaksanakan pemindahan dana guna memenuhi suatu kewajiban yang timbul dari suatu kegiatan ekonomi (Sofyan Abidin, 2015). Seiring berjalannya perkembangan teknologi ini seakan jadi kebutuhan atau ancaman yang akan dialami masyarakat dalam melakukan transaksi, karna tidak semua orang paham teknologi dan tidak semua orang suka menggunakan aplikasi mobile payment. Di Indonesia sendiri penggunaan pembayaran uang elektonik atau sistem pembayaran nontunai terus berkembang pesat dari nilai transaksinya yang naik setiap tahunnya (Infrastruktur Uang Elektronik, n.d.). Data transaksi uang elektronik sejak tahun 2015-2020 dapat dilihat pada Tabel 1. 


\section{Tabel 1.}

Transaksi Uang Elektronik Tahun 2015- 2020 (Berjalan)

\begin{tabular}{crrrrrrrrrr}
\hline Periode & 2015 & 2016 & 2017 & 2018 & 2019 & & & 2020 & \\
\cline { 7 - 11 } & & & & & & Jan & Feb & Maret & April & Mei \\
\hline \multirow{2}{*}{ Volume } & 535,579 & 683,133 & 943,319 & $2,922,6$ & $5,226,6$ & 457,94 & 431,467 & 401,00 & 324,87 & 298,187 \\
&, 528 &, 352 &, 933 & 98,905 & 99,919 & 4,919 &, 683 & 8,518 & 8,568 &, 348 \\
\hline \multirow{2}{*}{ Nominal } & $5,283,0$ & $7,063,6$ & 12,375, & 47,198, & 145,165 & 15,872, & 15,178, & 15,036, & $17,552,1$ & 15,033, \\
& 18 & 89 & 469 & 616 &, 468 & 433 & 625 & 070 & 19 & 708 \\
\hline \multicolumn{2}{l}{ Keterangan : Volume dalam satuan transaksi, Nominal dalam juta Rp } & & & &
\end{tabular}

Berdasarkan data di atas terlihat pertumbuhan yang signifikan dalam aktifitas pembayaran menggunakan uang elektronik yang termasuk juga dalam system pembayaran nontunai. Pembayaran dengan kartu atau juga disebut nontunai dinilai lebih efektif, efisien juga mudah. Saat ini masyarakat kota medan sudah banyak merasakan perkembangan dari system pembayaran nontunai ini. Dan semakin banyaknya akses untuk top up tanpa via bank penyelenggara sehingga muncul juga keinginan semua elemen masyarakat untuk melukan transaksi pembayaran dengan cara nontunai. Sistem pembayaran yang berkembang seiring dengan perkembangan zaman. Dulu sistem pembayaran lebih dikenal dengan sistem barter yaitu pertukaran antarbarang sesuai dengan kebutuhan dari pelaku barter itu sendiri. Kemudian sistem tersebut berkembang ketika mulai dikenal adanya satuan tertentu yang memiliki nilai pembayaran yang dikenal dengan sebutan uang. Hingga saat ini uang masih menjadi salah satu alat pembayaran utama yang berlaku di masyarakat. Selanjutnya sistem pembayaran terus berkembang dari sistem pembayaran tunai (cash) sampai saat ini ke sistem pembayaran nontunai (cashless).

Karakteristik setiap orang yang berbeda-beda juga dijadikan sasaran penelitian, dikarenakan masyarakat merupakan konsumen yang menentukan perkembangan kartu pembayaran elektronik atau nontunai yang akan datang. Preferensi masyarakat sendiridipengaruhi oleh beberapa faktor, pada penelitian ini akan diteliti 5 variabel yaitu: efisiensi, kewajiban, keamanan, kemudahan dan diskon. Preferensi masyarakat ini akan memengaruhi pengadopsian sistem pembayaran elektronik atau nontunai, dimana apabila penggunaan kartu pembayaran elektronik ini meningkat maka akan meningkatkan aktifitas perekonomian dan manfaat efisiensi bagi masyarakat itu sendiri. Preferensi adalah pilihan, kecenderungan atau kesukaan akan satu hal yang seseorang lakukan dalam melakukan aktivas kehidupan sehari-hari. Prefrensi ini biasanya digunakan untuk melihat seberapa jauh atau seberapa tertariknya sesorang akan suatu yang akan dilakukan. Dalam sistem pembayaran pun preferensi ini memiliki peranan besar. Preferensi konsumen didefinisikan sebagai selera subjektif (individu), yang diukur dengan utilitas, dari bundel berbagai barang. Konsumen dipersilahkan untuk melakukan rangking terhadap bundel barang yang diberikan pada 


\section{4 |Determinan Preferensi Masyarakat Kota Medan dalam Menggunakan Pembayaran Nontunai}

konsumen. Yang perlu diperhatikan adalah preferensi itu bersifat independen terhadap pendapatan dan harga.

Dalam berbagai literatur, efisiensi juga sering dikaitkan dengan produktivitas karena sama-sama menilai variabel input terhadap output. Pengertian produktivitas berkebalikan dengan pengertian efisiensi. Produktivitas dihitung dengan cara membagi output terhadap input (Hidayat, 2018; Rani \& Sulaiman, 2017). Sedangkan efisiensi adalah input dibagi dengan output (Nurhasanah \& Lubis, 2017; Wulandari \& Widiyanti, 2017).

Hak dan Kewajiban para pihak penerbit diwajibkan untuk memberikan informasi secara tertulis kepada pemegang kartu mengenai prosedur dan tata cara penggunaan kartu prabayar, fasilitas dan risiko yang mungkin muncul pada penggunaan kartu prabayar; Hak dan kewajiban pemegang kartu; Tata cara pengajuan pengaduan terkait penggunaan kartu dan perkiraan lamanya waktu penanganan pengaduan tersebut (Bank Indonesia, n.d.). Sementara itu, keamanan informasi intinya adalah bagaimana pihak bank dapat mencegah penipuan (cheating) atau paling tidak, mendeteksi adanya penipuan pada sistem yang berbasis informasi, dimana informasinya sendiri tidak memiliki arti fisik. Dimana saat ini keamanan informasi mengacu pada ISO 17799 (Ramadhani, 2018). Selain itu memang faktor keamanan informasi banyak diteliti sebagai faktor penting dalam pelaksanaan transaksi keuangan saat ini (Iskandar, 2017; Islami et al., 2016; Lenawati \& Winarno, 2017). Variabel penting lainnya adalah kemudahan penggunaan (ease of use) didefinisikan sebagai suatu keutamaan dimana seseorang percaya bahwa dengan menggunakan sebuah teknologi dapat membuat orang bebas dari upaya kejahatan di internet (cyber crime). Berbagai penelitian telah menyepakati bahwa variabel kemudahan penggunaan sangat penting (Iskandar, 2017; Mahemba, n.d.; Pratama \& Suputra, 2019; Rithmaya, 2016). Varibel lain yang juga menjadi determinan preferensi masyarakat adalah diskon juga merupakan potongan harga yang diberikan oleh penjual kepada pembeli sebagai penghargaan atas aktivitas tertentu dari pembeli yang menyenangkan bagi penjual. Penelitian terdahulu yang juga menjadikan diskon sebagai variabel X (Amalia \& Saryadi, 2018; Amani Salsabila, 2020; DEWI, 2019; Kusnawan et al., 2019). Sementara itu, terkait dengan variabel preferensi konsumen sangat banyak diteliti pada berbagai bidang. Dimana preferensi konsumen dalam bidang pembayaran digital maupun nontunai (Butarbutar, 2018; Krisdiana, 2018; Rifai \& Halim, 2020; Saputri, 2020).

\section{METODE PENELITIAN}

Pada penelitian menggunakan analisis deskriptif dan kuantitatif, yang merupakan uraian atau penjelasan dari hasil pengumpulan data yang kemudian dianalisis sehingga diperoleh gambaran yang jelas mengenai objek yang diteliti. Penelitian kuantitatif deskriptif 
yaitu, penelitian yang dilakukan untuk mengetahui nilai variabel mandiri, baik satu variabel atau lebih (independen) tanpa membuat perbandingan, atau menghubungkan dengan variabel yang lain. Adapun lokasi penelitian ini dilakukan di Kota Medan yang meliputi karyawan, pelaku usaha, mahasiswa serta para pengguna pembayaran nontunai. Dalam penelitian ini, kuesioner disebarkan pada sampel sebanyak 400 responden kemudian item pertanyaan terlebih dahulu diuji validitas dan reliabilitas. Selanjutnya diuji asumsi klasik, lalu diuji dengan uji t untuk mendapatkan pengaruh masing-masing variabel yang diteliti, lalu dilakukan uji $\mathrm{F}$ untuk mendapatkan pengaruh seluruh variabel secara bersama-sama (simultan) terhadap preferensi menggunakan pembayaran nontunai.

\section{HASIL DAN PEMBAHASAN}

Berdasarkan hasil pengolahan data dengan SPSS, berikut adalah hasil uji validitas terhadap seluruh item pertanyaan yang disebarkan melalui kueioner kepada responden penelitian. Berdasarkan hasil uji validitas diketahui bahwa seluruh item pertanyaan pada variabel efisiensi sudah valid.

Tabel 2.

Hasil Uji Validitas Variabel Efisiensi (X1)

\begin{tabular}{lccccc}
\hline & $\begin{array}{c}\text { Scale Mean } \\
\text { if Item } \\
\text { Deleted }\end{array}$ & $\begin{array}{c}\text { Scale } \\
\text { Variance if } \\
\text { Item } \\
\text { Deleted }\end{array}$ & $\begin{array}{c}\text { Corrected } \\
\text { Item-Total } \\
\text { Correlation }\end{array}$ & $\begin{array}{c}\text { Cronbach's } \\
\text { Alpha if } \\
\text { Item } \\
\text { Deleted }\end{array}$ & Keterangan \\
\hline Pertanyaan1 & 11,2500 & 1,321 &, 681 &, 666 & Valid \\
\hline Pertanyaan2 & 11,5000 &, 872 &, 669 &, 677 & Valid \\
\hline Pertanyaan3 & 11,2250 & 1,512 &, 359 &, 805 & Valid \\
\hline Pertanyaan4 & 11,2500 & 1,321 &, 681 &, 666 & Valid \\
\hline
\end{tabular}

Sumber : Data diolah, 2020

Sementara hasil uji validitas pada seluruh item pertanyaan variabel kewajiban juga sudah valid. Selengkapnya dapat dilihat pada tabel 3 .

Tabel 3.

Hasil Uji Validitas Variabel Kewajiban (X2)

\begin{tabular}{ccccc}
$\begin{array}{c}\text { Scale Mean } \\
\text { if Item } \\
\text { Deleted }\end{array}$ & $\begin{array}{c}\text { Scale } \\
\text { Variance if } \\
\text { Item } \\
\text { Deleted }\end{array}$ & $\begin{array}{c}\text { Corrected } \\
\text { Item-Total } \\
\text { Correlation }\end{array}$ & $\begin{array}{c}\text { Cronbach's } \\
\text { Alpha if } \\
\text { Item } \\
\text { Deleted }\end{array}$ & Keterangan \\
11,1000 & 1,426 &, 664 &, 621 & Valid \\
\hline 11,3250 & 1,148 &, 521 &, 700 & Valid \\
\hline 11,1750 & 1,533 &, 532 &, 683 & Valid \\
11,3250 & 1,353 &, 477 &, 708 & Valid \\
\hline
\end{tabular}

Sumber : Data diolah, 2020

Demikian halnya juga pada hasil uji validitas item pertanyaan pada variabel keamanan dinyatakan valid. Selengkapnya terdapat pada tabel 4 . 
Tabel 4.

Hasil Uji Validitas Variabel Keamanan (X3)

\begin{tabular}{cccccc}
\hline & $\begin{array}{c}\text { Scale Mean } \\
\text { if Item } \\
\text { Deleted }\end{array}$ & $\begin{array}{c}\text { Scale } \\
\text { Variance if } \\
\text { Item Deleted }\end{array}$ & $\begin{array}{c}\text { Corrected } \\
\text { Item-Total } \\
\text { Correlation }\end{array}$ & $\begin{array}{c}\text { Cronbach's } \\
\text { Alpha if } \\
\text { Item } \\
\text { Deleted }\end{array}$ & Keterangan \\
\hline Pertanyaan 9 & 11,6000 & 1,477 &, 792 &, 730 & Valid \\
\hline Pertanyaan 10 & 11,6000 & 1,272 &, 902 &, 667 & Valid \\
\hline Pertanyaan 11 & 11,6750 & 1,558 &, 781 &, 740 & Valid \\
\hline Pertanyaan 12 & 11,9250 & 2,122 &, 261 &, 942 & Valid \\
\hline Sumber: Data diolah & $\mathbf{2 0 2 0}$ & & & &
\end{tabular}

Sumber : Data diolah, 2020

Selanjutnya, pada hasil uji validitas item pertanyaan pada variabel kemudahan dinyatakan valid. Selengkapnya terdapat pada tabel 5 .

Tabel 5.

Hasil Uji Validitas Variabel Kemudahan (X4)

\begin{tabular}{lccccc}
\hline & $\begin{array}{c}\text { Scale Mean } \\
\text { if Item } \\
\text { Deleted }\end{array}$ & $\begin{array}{c}\text { Scale } \\
\text { Variance if } \\
\text { Item Deleted }\end{array}$ & $\begin{array}{c}\text { Corrected Item- } \\
\text { Total } \\
\text { Correlation }\end{array}$ & $\begin{array}{c}\text { Cronbach's } \\
\text { Alpha if } \\
\text { Item } \\
\text { Deleted }\end{array}$ & Keterangan \\
\hline Pertanyaan 13 & 11,3250 & 1,302 &, 619 &, 715 & Valid \\
\hline Pertanyaan 14 & 11,0750 & 2,020 &, 400 &, 804 & Valid \\
\hline Pertanyaan 15 & 11,2000 & 1,497 &, 786 &, 628 & Valid \\
\hline Pertanyaan 16 & 11,1000 & 1,477 &, 591 &, 720 & Valid \\
\hline
\end{tabular}

Sumber : Data diolah, 2020

Selanjutnya, pada hasil uji validitas item pertanyaan pada variabel diskon dinyatakan valid. Selengkapnya terdapat pada tabel 6.

Tabel 6.

Hasil Uji Validitas Variabel Diskon (X5)

\begin{tabular}{lccccc}
\hline & $\begin{array}{c}\text { Scale Mean } \\
\text { if Item } \\
\text { Deleted }\end{array}$ & $\begin{array}{c}\text { Scale } \\
\text { Variance if } \\
\text { Item } \\
\text { Deleted }\end{array}$ & $\begin{array}{c}\text { Corrected } \\
\text { Item-Total } \\
\text { Correlation }\end{array}$ & $\begin{array}{c}\text { Cronbach's } \\
\text { Alpha if } \\
\text { Item } \\
\text { Deleted }\end{array}$ & Keterangan \\
\hline Pertanyaan17 & 11,9750 & 1,512 &, 445 &, 771 & Valid \\
\hline Pertanyaan18 & $\mathbf{1 1 , 5 5 0 0}$ & $\mathbf{2 , 1 5 1}$ &, 267 &, 813 & Valid \\
\hline Pertanyaan19 & $\mathbf{1 1 , 5 0 0 0}$ & $\mathbf{1 , 2 3 1}$ &, 774 &, 545 & Valid \\
\hline Pertanyaan20 & $\mathbf{1 1 , 6 2 5 0}$ & 1,471 &, 797 &, 567 & Valid \\
\hline
\end{tabular}

Sumber : Data diolah, 2020

Selanjutnya, pada hasil uji validitas item pertanyaan pada variabel preferensi masyarakat dinyatakan valid. Selengkapnya terdapat pada tabel 7.

Tabel 7

Uji Validitas Preferensi Masyarakat (Y)

\begin{tabular}{lccccc}
\hline & $\begin{array}{c}\text { Scale Mean if } \\
\text { Item Deleted }\end{array}$ & $\begin{array}{c}\text { Scale } \\
\text { Variance if } \\
\text { Item Deleted }\end{array}$ & $\begin{array}{c}\text { Corrected } \\
\text { Item-Total } \\
\text { Correlation }\end{array}$ & $\begin{array}{c}\text { Cronbach's } \\
\text { Alpha if Item } \\
\text { Deleted }\end{array}$ & Keterangan \\
\hline Pertanyaan21 & 11,1000 & 1,477 &, 751 &, 720 & Valid \\
\hline Pertanyaan22 & 11,3500 & 1,105 &, 612 &, 806 & Valid \\
\hline Pertanyaan23 & 11,1000 & 1,477 &, 751 &, 720 & Valid \\
\hline Pertanyaan24 & 11,2250 & 1,512 &, 526 &, 805 & Valid \\
\hline
\end{tabular}

Sumber : Data diolah, 2020

Kesimpulannya bahwa semua item pertanyaan pada seluruh variabel efisiensi, kewajiban, keamanan, kemudahan, diskon dan preferensi masyarakat adalah valid sesuai hasil uji validitas dengan bantuan SPSS. Setelah melakukan uji validitas maka selanjutnya 
adalah melakukan uji reliabilitas pada semua item pertanyaan baik variabel X maupun Y. Berdasarkan hasil uji reliabilitas, diketahui bahwa seluruh item pertanyaan reliabel. Hasil uji reliabilitas menunjukan bahwa nilai cronbach's alfa memiliki nilai > dari o,736-0,834 ini menunjukan bahwa semua variabel yang diteliti mulai dari Efisiensi, Kewajiban, Keamanan, Kemudahan masing-masing bernilai reliabel dan sangat reliabel sehingga dapat digunakan dalam penelitian. Selengkapnya dapat dilihat pada Tabel 8.

Tabel 8.

Hasil Uji Reliabilitas

\begin{tabular}{lcc}
\hline \multicolumn{1}{c}{ Variabel } & Nilai Cronbach Alpha & Keterangan \\
\hline Efisiensi (X1) & 0,765 & Reliabel \\
\hline Kewajiban (X2) & 0,736 & Reliabel \\
\hline Keamanan (X3) & 0,834 & Sangat Reliabel \\
\hline Kemudahan (X4) & 0,778 & Reliabel \\
\hline Diskon (X5) & 0,752 & Reliabel \\
\hline Preferensi Masyarakat (Y) & 0,809 & Sangat Reliabel
\end{tabular}

Sumber : Data diolah, 2020

Hasil pengujian asumsi klasik dapat dilihat mulai dari hasil uji normalitas, dimana uji normalitas merupakan salah satu bagian dari uji asumsi klasik. Tujuannya untuk mengetahui apakah distribusi sebuah data mengikuti atau mendekati distribusi normal.

Tabel 9.

Hasil Uji Normalitas dengan Kolmogrov Smirnov

\begin{tabular}{ccc}
\hline & & Unstandardized Residual \\
\hline & & 400 \\
\hline Normal Parameters ${ }^{\mathbf{a}, \mathbf{b}}$ & Mean &, 0000000 \\
\hline & Std. Deviation & 1,52503774 \\
\hline Most Extreme Differences & Absolute &, 109 \\
\hline Kolmogorov-Smirnov $\mathbf{Z}$ & Positive &, 071 \\
\hline Asymp. Sig. (2-tailed) & Negative &,- 109 \\
\hline Sum & & 1,085 \\
\hline
\end{tabular}

Sumber : Data diolah, 2020

Berdasarkan tabel diatas, dapat dilihat bahwa nilai Kolmogorov-Smirnov (K-S) yang diperoleh Y adalah 1,08 dan tingkat signifikansi pada 0,190 yang lebih besar dari tingkat signifikansi 0,05. Dengan demikian dapat disimpulkan bahwa data dalam model regresi telah terdistribusi secara normal. Selanjutanya dilakukan uji heterskedastisitas dengan hasil seperti pada Gambar 1. 


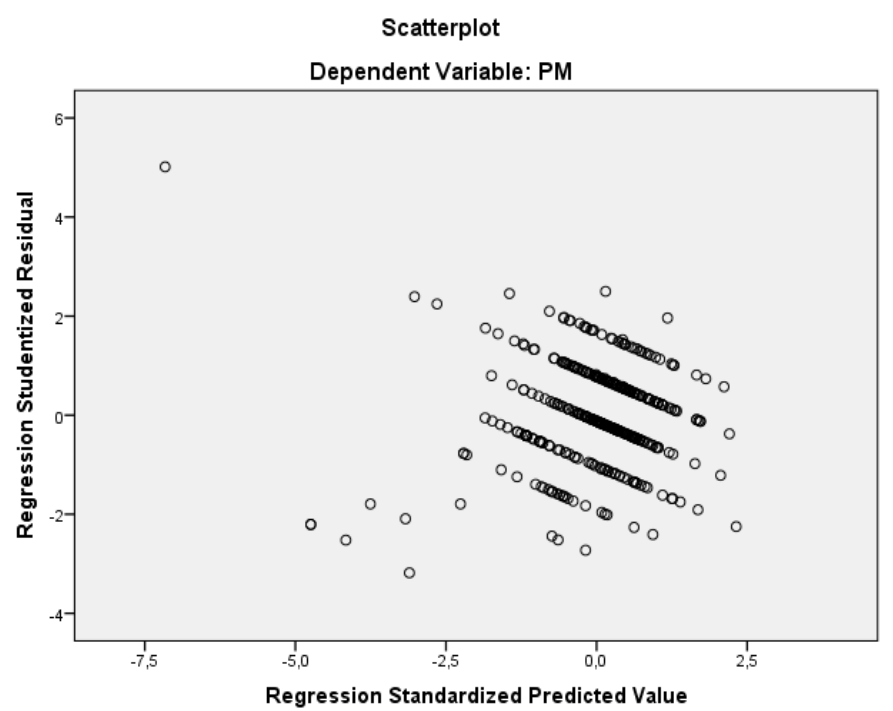

Gambar.1 Scatterplot

Dilihat dari gambar di atas bahwa data tidak memiliki gangguan heteroskedastisitas karena tidak ada pola tertentu. Lalu dilanjutkan dengan uji multikolonieritas dengan hasil seperti pada Tabel 10.

Tabel 10.

Hasil Uji Multikolinearitas

\begin{tabular}{|c|c|c|c|c|c|c|c|}
\hline \multirow[t]{2}{*}{ Model } & \multicolumn{2}{|c|}{$\begin{array}{l}\text { Unstandardized } \\
\text { Coefficients }\end{array}$} & \multirow{2}{*}{$\begin{array}{c}\begin{array}{c}\text { Standardized } \\
\text { Coefficients }\end{array} \\
\text { Beta }\end{array}$} & \multirow[t]{2}{*}{$t$} & \multirow[t]{2}{*}{ Sig. } & \multicolumn{2}{|c|}{$\begin{array}{l}\text { Collinearity } \\
\text { Statistics }\end{array}$} \\
\hline & B & $\begin{array}{l}\text { Std. } \\
\text { Error }\end{array}$ & & & & Tolerance & VIF \\
\hline (Constant) & 7,468 & ,927 & & 8,055 & , 000 & & \\
\hline Efisiensi & ,126 & ,056 & ,119 & 2,244 & ,025 & ,709 & 1,410 \\
\hline Kewajiban & ,154 &, 052 & ,177 & 2,985 & ,003 &, 565 & 1,769 \\
\hline Keamanan & ,197 &, 096 & ,178 & 2,062 & ,045 &, 562 & 1,781 \\
\hline Kemudahan & ,231 &, 048 & ,276 & 4,817 & ,000 & 605 & 1,653 \\
\hline Diskon & ,086 & ,041 & ,119 & 2,083 & ,038 & ,607 & 1,649 \\
\hline
\end{tabular}

Berdasarkan tabel di atas, dapat dilihat bahwa tidak ada variabel bebas yang memiliki nilai VIF lebih dari 10 dan tidak ada variabel bebas yang memiliki nilai tolerance lebih kecil dari 0,1. Dengan demikian dapat disimpulkan bahwa penelitian ini terbebas dari multikolinearitas. Analisis data selanjutnya adalah analisi linier berganda, dengan hasil sesuai pada pada Tabel 11 .

Tabel. 11

Hasil Analisis Regresi Linier Berganda 


\begin{tabular}{|c|c|c|c|c|c|}
\hline \multirow[t]{2}{*}{ Model } & \multicolumn{2}{|c|}{ Unstandardized Coefficients } & \multirow{2}{*}{$\begin{array}{c}\begin{array}{c}\text { Standardized } \\
\text { Coefficients }\end{array} \\
\text { Beta }\end{array}$} & \multirow[t]{2}{*}{$\mathbf{T}$} & \multirow[t]{2}{*}{ Sig. } \\
\hline & B & Std. Error & & & \\
\hline (Constant) & 7,468 & ,927 & & 8,055 & ,000 \\
\hline Efisiensi & ,126 &, 056 & ,119 & 2,244 & ,025 \\
\hline Kewajiban & ,154 &, 052 & 177 & 2,985 & ,003 \\
\hline Keamanan & 197 &, 096 & , 178 & 2,062 & 045 \\
\hline Kemudahan & ,231 &, 048 & 276 & 4,817 & , 000 \\
\hline Diskon & ,o86 & ,041 & ,119 & 2,083 &, 038 \\
\hline
\end{tabular}

Sumber : Data diolah, 2020

Berdasarkan hasil tersebut, maka persamaan regresinya adalah sebagai berikut ini:

$$
\begin{aligned}
& \mathrm{Y}=\mathrm{a}+\mathrm{b}_{1} \mathrm{X}_{1}+\mathrm{b}_{2} \mathrm{X}_{2}+\mathrm{b}_{3} \mathrm{X}_{3}+\mathrm{b}_{4} \mathrm{X}_{4}+\mathrm{b}_{5} \mathrm{X}_{5}+\mathrm{e} \\
& \mathrm{Y}=7,468+0,126 \mathrm{X1}+0,154 \mathrm{X2}_{2}+0,197 \mathrm{X}_{3}+0,231 \mathrm{X}_{4}+0,086 \mathrm{X}_{5}+\mathrm{e}
\end{aligned}
$$

Dari persamaan di atas diketahui bahwa semua variabel $\mathrm{X}$ (efisiensi, kewajiban, keamanan, kemudahan, discon) memiliki koefisien yang positif, berarti variabel bebas mempunyai pengaruh yang searah terhadap variabel Y ( preferensi masyarakat ) sedangkan variabel keamanan negatif. Model penelitian dalam bentuk persamaan regresi linear berganda diatas dapat dilihat sebagai berikut ini :

Artinya dari hasil regresi adalah

1. Nilai konstant 7,468 artinya jika variabel $\mathrm{X}_{1}, \mathrm{X}_{2}, \mathrm{X}_{3}, \mathrm{X}_{4}$ dan $\mathrm{X}_{5}$ sama dengan $\mathrm{o}$, maka Apabila variabel lain bernilai konstan maka nilai preferensi masyarakat melakukan pembayaran nontunai akan berubah dengan sendirinya sebesar nilai konstan yaitu 7,468

2. Nilai koofesien $\mathrm{X} 1$ 0,126, jika jumlah efisiensi meningkat $1 \mathrm{Y}=0,126$. Maka Apabila variabel lain bernilai konstan, nilai preferensi masyarakat melakukan pembayaran nontunai akan berubah sebesar nilai konstan yaitu 0,126 setiap satu satuan efisiensi.

3. Nilai koofesien X1 0,154, jika jumlah kewajiban meningkat $1 \mathrm{Y}=0,154$ Maka Apabila variabel lain bernilai konstan, nilai preferensi masyarakat melakukan pembayaran nontunai akan berubah sebesar nilai konstan yaitu o,154 setiap satu satuan kewajiban.

4. Nilai koofesien $X_{3}$ 0,197 jika jumlah keamanan meningkat $1 \mathrm{Y}=$ 0,197 Maka Apabila variabel lain bernilai konstan, nilai preferensi masyarakat melakukan pembayaran nontunai akan berubah sebesar nilai konstan yaitu 0,197 setiap satu satuan keamanan.

5. Nilai koofesien $\mathrm{X}_{4}$ 0,231, jika jumlah kemudahan meningkat $1 \mathrm{Y}=0,231$. Maka Apabila variabel lain bernilai konstan, nilai preferensi masyarakat melakukan pembayaran nontunai akan berubah sebesar nilai konstan yaitu 0,231 setiap satu satuan kemudahan.

6. Nilai koofesien $\mathrm{X} 1 \mathrm{0}, 086$, jika jumlah discon meningkat $1 \mathrm{Y}=0,086$. Maka Apabila variabel lain bernilai konstan, nilai preferensi masyarakat melakukan pembayaran nontunai akan berubah sebesar nilai konstan yaitu o,o86 setiap satu satuan discon.

Selanjutnya adalah melakukan pengujian hipotesis dengan uji t dengan hasil seperti pada tabel 12. 
170 |Determinan Preferensi Masyarakat Kota Medan dalam Menggunakan

Pembayaran Nontunai

Tabel 12

Hasil Uji t (Parsial)

\begin{tabular}{|c|c|c|c|c|c|}
\hline \multirow[t]{2}{*}{ Model } & \multicolumn{2}{|c|}{ Unstandardized Coefficients } & \multirow{2}{*}{$\begin{array}{c}\text { Standardized } \\
\text { Coefficients } \\
\text { Beta }\end{array}$} & \multirow[t]{2}{*}{$\mathbf{T}$} & \multirow[t]{2}{*}{ Sig. } \\
\hline & B & Std. Error & & & \\
\hline (Constant) & 7,468 & ,927 & & 8,055 & ,000 \\
\hline Efisiensi & ,126 & ,056 & ,119 & 2,244 & ,025 \\
\hline Kewajiban & ,154 & ,052 & 177 & 2,985 & ,003 \\
\hline Keamanan & ,197 & ,096 & ,178 & 2,062 & ,045 \\
\hline Kemudahan & ,231 &, 048 &, 276 & 4,817 & ,OOO \\
\hline Diskon & 086 & 041 & 119 & 2,083 & ,038 \\
\hline
\end{tabular}

Sumber : Data diolah, 2020

Uji t-test dalam penelitian ini bertujuan untuk melihat besarnya pengaruh masingmasing variabel independen secara parsial (individual) terhadap variabel dependen. Dalam hal ini, dasar pengambilan keputusan adalah dengan membandingkan $t$ tabel dengan $t$ hitung. Berdasarkan hasil uji $\mathrm{t}$ di atas diketahui dk (derajat kebebasan) $=400-6=394$ dengan taraf jarak $\alpha=0,05$ maka t-tabel sebesar 1,967. Pedoman yang digunakan untuk menerima atau menolak hipotesis yaitu:

Ha diterima jika t-hitung > t-tabel , atau nilai p-value pada kolom sig. < level of significant (a) $5 \%$.

Ho diterima jika t-hitung < t-tabel, atau nilai p-value pada kolom sig. > level of significant (a) $5 \%$.

Hasil uji t menunjukkan hasil parsialnya adalah sebagai berikut :

1) Variabel Efisiensi

$\mathrm{T}_{\text {hitung }}$ Efisiensi $=$ 2,244 maka diperoleh thitung $>\mathrm{t}$ tabel atau 2,244 > 1,967 Dari hasil uji t tersebut, diperoleh bahwa Ha diterima.

2) Variabel Kewajiban

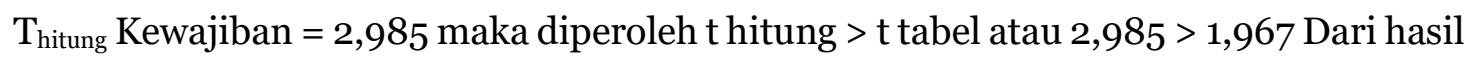
uji t tersebut, diperoleh bahwa Ha diterima

3) Variabel Keamanan

$\mathrm{T}_{\text {hitung Keamanan }}=$ 2,062 maka diperoleh thitung $>\mathrm{t}$ tabel atau $>=$ 2,062 $>$ 1,967 Dari hasil uji t tersebut, diperoleh bahwa Ha diterima

4) Variabel Kemudahan

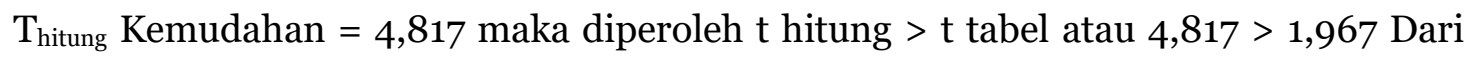
hasil uji t tersebut, diperoleh bahwa Ha diterima

5) Variabel Discon

$\mathrm{T}_{\text {hitung }}$ Discon $=$ 2,083 maka diperoleh t hitung $>\mathrm{t}$ tabel atau 2,083 $>1,967$ Dari hasil uji t tersebut, diperoleh bahwa Ha diterima 
Selanjutnya dilakukan uji $\mathrm{F}$ untuk menguji pengaruh simultan pada variabel independen efisiensi, kewajiban, keamanan kemudahan, dan diskon terhadap preferensi masyarakat mengunakan uang elektronik atau pembayaran nontunai di Kota Medan secara bersama-sama. Hasil selengkapnya pada Tabel 13.

Pedoman yang digunakan untuk menerima atau menolak hipotesis yaitu:

Ha diterima jika F-hitung > F-tabel, atau nilai p-value pada kolom sig. < level of significant (a) $5 \%$.

Ho diterima jika F-hitung < F-tabel, atau nilai p-value pada kolom sig. > level of significant (a) $5 \%$.

Tabel. 13 Hasil Uji F (Simultan)

\begin{tabular}{cccccc}
\hline Model & $\begin{array}{c}\text { Sum of } \\
\text { Squares }\end{array}$ & Df & Mean Square & F & Sig. \\
\hline Regression & 134,595 & 5 & 26,919 & 21,640 &, OOO $^{\mathrm{b}}$ \\
\hline Residual & 490,115 & 394 & 1,244 & & \\
\hline Total & 624,710 & 399 & & & \\
\hline
\end{tabular}

Sumber: Data Diolah, 2020

Nilai F-hitung adalah 21,640 dan F-tabel adalah (df1) k-1=6-1=5 (df2) n - k = 400 - $6=394$ atau F-hitung > F-tabel atau 21,640 > 2,251 atau nilai p-value adalah o,ooo pada kolom sig. < level of significant (a) $5 \%$ maka terdapat pengaruh secara simultan antara efisiensi, kewajiban, keamanan kemudahan, dan discon terhadap preferensi masyarakat mengunakan uang elektronik di Kota Medan.

Untuk mengetahui derajat keeratan pengaruh variabel efisiensi, kewajiban, keamanan kemudahan, dan discon terhadap preferensi masyarakat mengunakan uang elektronik di Kota Medan maka dapat digunakan korelasi ganda dan dengan carra melihat nilai koefisien determinasi (R-Square) akan dapat diketahui bagaimana sebenarnya nilai kontribusi kedua variabel bebas terhadap terikat seperti pada Tabel 14 .

Tabel 14

Hasil Determinasi

\begin{tabular}{ccccc}
\hline Model & R & R Square & $\begin{array}{c}\text { Adjusted R } \\
\text { Square }\end{array}$ & $\begin{array}{c}\text { Std. Error of the } \\
\text { Estimate }\end{array}$ \\
\hline $\mathbf{1}$ &, $981^{\mathrm{a}}$ &, 963 &, 958 &, 31160 \\
\hline
\end{tabular}

Sumber: Data Diolah, 2020

Dari tabel di atas terlihat bahwa secara bersamaan nilai koefisien korelasi ganda sebesar 0,963 bernilai positif, artinya berpengaruh variabel efisiensi, kewajiban, keamanan kemudahan, dan discon terhadap preferensi masyarakat sangat kuat, atau 96,3\% variabel 


\section{2 |Determinan Preferensi Masyarakat Kota Medan dalam Menggunakan Pembayaran Nontunai}

terikat dapat dipengaruhi oleh variabel bebas, sementara 3,7\% dipengaruhi oleh variabel lain yang tidak diteliti.

Sistem pembayaran elektronik atau nontunai juga memungkinkan masyarakat dan perusahaan-perusahaan untuk menekan biaya operasionalnya seperti biaya transportasi untuk menyetorkan uang ke bank beserta biaya pengawalannya. Di sisi lain yang membuatnya menjadi lebih efisien, BI pun dapat berhemat dalam hal biaya pengelolaan uang rupiah yang meliputi perencanaan, pencetakan, pengeluaran, pengedaran, pencabutan dan penarikan, serta pemusnahan. Serta Kewajiban memiliki tolak ukur yang didasarkan pada jumlah penggunaan dan keragaman dari aplikasi yang digunakan. Semakin beragamnya aplikasi atau fasilitas alat pembayaran nontunai yang digunakan oleh masyarakat dan banyaknya masyarakat yang menggunakan aplikasi tersebut mengisyaratkan bahwa teknologi memiliki manfaat yang tinggi yang dirasakan oleh masyarakat pengguna alat pembayaran nontunai. Keamanan juga berkaitan dengan rasa nyaman yang dirasakan oleh pengguna yang selanjutnya berdampak pada peningkatan intensitas penggunaan alat pembayaran nontunai. Serta dimana berkaitan juga dengan faktor kemudahan penggunaan, kemudahan pengguna tersebut tersebut didukung faktor keamanan yang mengisyaratkan pembayaran ini aman karna transaksi menggunakan pin dan tidak membawa uang tunai serta mudah karna sudah tersebar dibanyak tempat. Sehingga faktor keamanan berpengaruh secara tidak langsung terhadap peningkatan intensitas penggunaan pembayaran yang menggunakan kartu ataupun aplikasi. Selanjutnya, masyarakat menjadi konsumtif karena uang elektronik menawarkan banyak kemudahan. Belum lagi, perusahaan penyedia uang elektronik gemar menebar discon bagi penggunaannya. Kelebihan transaksi nontunai yang paling menarik. Biasanya kartu kredit dan aplikasi pembayaran menawarkan banyak promo diskon untuk bertransaksi di merchant-merchant restaurant, maskapai penerbangan, atau toko-toko tertentu sehingga membuat masyarakat lebih condong menggunakan pembayaran nontunai.

\section{KESIMPULAN}

Secara parsial dan simultan efisiensi, kewajiban, keamanan kemudahan, dan diskon berpengaruh positif dan signifikan terhadap preferensi masyarakat. Ini menyimpulkan bahwasanya masyarakat sudah menyukai transaksi nontunai dan ini sinyal positif bagi para pemangku kepentingan untuk membuat pelayanan pembayaran melalui transaksi nontunai menjadi lebih baik lagi sehingga masyarakat semakin banyak menggunakan transaksi nontunai. 


\section{DAFTAR PUSTAKA}

Amalia, N. R., \& Saryadi, S. (2018). PENGARUH KEMUDAHAN AKSES DAN DISKON TERHADAP KEPUTUSAN PEMBELIAN PADA SITUS ONLINE TIKET. COM. Jurnal Ilmu Administrasi Bisnis, 7(3), 404-414.

Amani Salsabila, N. (2020). PENGARUH DISKON DAN PROMOSI TERHADAP KEPUTUSAN PEMBELIAN PRODUK SIMPLICITY (STUDI PADA STORE SIMPLICITY PLAZA SURABAYA) [PhD Thesis]. UPN" Veteran" Jawa Timur.

Bank Indonesia. (n.d.). Retrieved December 28, 2020, from https://www.bi.go.id/id/default.aspx

Butarbutar, N. A. (2018). ANALISIS FAKTOR-FAKTOR YANG MEMPENGARUHI MINAT PENGGUNAAN PEMBAYARAN NON TUNAI PADA APLIKASI TRANSPORTASI ONLINE DI KOTA MALANG. Jurnal Ilmiah Mahasiswa FEB, 6(2), Article 2. https://jimfeb.ub.ac.id/index.php/jimfeb/article/view/4778

DEWI, B. R. S. (2019). PENGARUH DISKON DAN HADIAH TERHADAP PENGGUNAAN KARTU KREDIT (STUDI PADA PEMANDIRING KARTU KREDIT BANK MANDIRI CABANG MATARAM). GANEC SWARA, 13(2), 221-229.

Hidayat, H. (2018). Analisis Model Perhitungan Produktivitas Karyawan. Jurnal Mitra Manajemen, 2(2), 104-114.

Hidayati, S., Nuryanti, I., Firmansyah, A., Fadly, A., \& Darmawan, I. Y. (2006). Operasional Emoney. Bank Indonesia, 1-5.

Infrastruktur Uang Elektronik. (n.d.). Retrieved December 28, 2020, from https://www.bi.go.id/id/statistik/ekonomi-keuangan/ssp/uang-elektronikinfrastruktur.aspx

Iskandar, S. (2017). FAKTOR-FAKTOR YANG MEMPENGARUHI NIAT BELI KONSUMEN E-COMMERCE BERDASARKAN KERANGKA TECHNOLOGY ACCEPTANCE MODEL (TAM), DENGAN PERSEPSI KEAMANAN INFORMASI DAN PRIVASI SEBAGAI FAKTOR MEDIASI [PhD Thesis]. Unika Soegijapranata Semarang.

Islami, D. C., IH, K. B., \& Candiwan, C. (2016). Kesadaran Keamanan Informasi pada Pegawai Bank x di Bandung Indonesia. INKOM Journal, 1O(1), 19-26.

Krisdiana, S. (2018). ANALISIS PREFERENSI KONSUMEN PENGGUNA TRANSPORTASI ONLINE PADA SISTEM PEMBAYARAN DIGITAL (STUDI KASUS PENGGUNA GOJEK DI KOTA MALANG). Jurnal Ilmiah Mahasiswa FEB, 6(2), Article 2. https://jimfeb.ub.ac.id/index.php/jimfeb/article/view/5003

Kusnawan, A., Diana, S., Andy, A., \& Tjong, S. (2019). Pengaruh Diskon pada Aplikasi e-Wallet terhadap Pertumbuhan Minat Pembelian Impulsif Konsumen Milenial di Wilayah Tangerang. Sains Manajemen, 5(2). 
174 |Determinan Preferensi Masyarakat Kota Medan dalam Menggunakan Pembayaran Nontunai

Lenawati, M., \& Winarno, W. W. (2017). Tata Kelola Keamanan Informasi Pada PDAM Menggunakan ISO/IEC 27001: 2013 Dan Cobit 5. Speed-Sentra Penelitian Engineering Dan Edukasi, 9(1).

Mahemba, Y. (n.d.). PENGARUH PERSEPSI MANFAAT PENGGUNAAN (PRECEIVED USEFULNESS) DAN PERSEPSI KEMUDAHAN PENGGUNAAN (PRECEIVED EASE OF USE) TERHADAP KINERJA PROGRAM AKUNTASI PADA UMKM DI KOTA YOGYAKARTA.

Nur, F. M. (2013). E-Money: Solusi Transaksi Mikro Modern. Jurnal Ilmu Manajemen, 3(1), $443-452$.

Nurhasanah, S., \& Lubis, D. (2017). Efisiensi Kinerja BAZNAS Bogor Dan Sukabumi: Pendekatan Data Envelopment Analysis. Jurnal Akuntansi Dan Keuangan Islam, 5(2), $105-120$.

Pratama, A. B., \& Suputra, I. D. G. D. (2019). Pengaruh Persepsi Manfaat, Persepsi Kemudahan Penggunaan, dan Tingkat Kepercayaan Pada Minat Menggunakan Uang Elektronik. EJurnal Akuntansi, 27(2), 927-953.

Ramadhani, A. (2018). Keamanan Informasi. Nusantara-Journal of Information and Library Studies, 1(1), 39-51.

Rani, B. F., \& Sulaiman, O. K. (2017). TEKNOLOGI BERORIENTASI MODEL PENGUKURAN PRODUKTIVITAS.

Rifai, D. F., \& Halim, A. (2020). PREFERENSI MASYARAKAT DI KOTA MAKASSAR DALAM MENGGUNAKAN E-MONEY FINTECH SEBAGAI ALAT PEMBAYARAN ELEKTRONIK. SEIKO: Journal of Management \& Business, 3(3), 202-213. https://doi.org/10.37531/sejaman.v3i3.739

Rithmaya, C. L. (2016). Pengaruh Kemudahan Penggunaan, Kemanfaatan, Sikap, Risiko Dan Fitur Layanan Terhadap Minat Ulang Nasabah Bank Bca Dalam Menggunakan Initernet Banking. Jurnal Riset Ekonomi Dan Manajemen, 16(1), 160-177.

Rohmah, F. (n.d.). Perkembangan Uang Elektronik pada Perdagangan di Indonesia Oleh.

Saputri, O. B. (2020). Preferensi konsumen dalam menggunakan quick response code indonesia standard (qris) sebagai alat pembayaran digital. KINERJA, 17(2), 237-247. https://doi.org/10.29264/jkin.v17i2.7355

Sofyan Abidin, M. (2015). Dampak Kebijakan E-Money Di Indonesia Sebagaialat Sistem Pembayaran Baru. Jurnal Akuntansi Akunesa, 3(2).

TOC - Bagaimana Implementasi Pembayaran Non Tunai Berbasis Aplikasi yang Ideal? (n.d.). Retrieved December 28, 2020, from http://himaep.feb.unair.ac.id/thinkingout-cloud/158-toc-bagaimana-implementasi-pembayaran-non-tunai-berbasisaplikasi-yang-ideal.html 
Wulandari, R. S., \& Widiyanti, A. (2017). PERANCANGAN PENGUKURAN EFISIENSI KINERJA PROGRAM PENDAMPINGAN DESA DI KABUPATEN SIDOARJO DENGAN METODE DEA. Seminar Nasional Sains Dan Teknologi Terapan V. 